\title{
Knowledge Levels of Preschool Teachers about Airway Obstruction due to Foreign Body
}

\author{
(1) Hatice Gencer, ${ }^{1}$ (D) Ahmet Ergin, ${ }^{2}$ (1) Süleyman Utku Uzun ${ }^{3}$ \\ 'Department of Public Health, Pamukkale University Faculty of Medicine, Denizli, Turkey \\ ${ }^{2}$ Department of Public Health and Department of Pediatrics and Child Health, Social Pediatrics Unit, Pamukkale \\ University Faculty of Medicine, Denizli, Turkey \\ ${ }^{3}$ Department of Public Health, Epidemiology Division, Pamukkale University Faculty of Medicine, Denizli, Turkey
}

\section{ABSTRACT}

Objectives: This study aims to investigate the knowledge levels of preschool teachers who work in Denizli city center in Turkey about foreign body airway obstruction (FBAO).

Methods: The population of this cross-sectional study consists of 432 preschool teachers working in primary schools and kindergartens located in Denizli city center. Participants were administered a questionnaire that consisted of 28 questions. For each participant, the knowledge scores about FBAO were calculated. Each participant can score a minimum of 0.0 and maximum of 28.0 points.

Results: For this study, 204 preschool teachers working in 27 schools were selected. The mean age of the participants was $33.5 \pm 5.3$ years and 185 (98.4\%) were female. Twenty-three (12.2\%) of the teachers had previously come across airway obstruction due to foreign body. One hundred forty-two (76.3\%) of the participants find their knowledge levels insufficient and 151 (80.7\%) of them want to get educated. Teachers' knowledge score about FBAO was $11.6 \pm 5.5$. Teachers' knowledge scores who had two and more children and those who get educated before were higher and teachers' knowledge scores who want additional education were found to be lower $(p=0.010, p<0.001$ and $p<0.001$, respectively).

Conclusion: The knowledge level of preschool teachers in Turkey about FBAO was low. Teachers were aware of this insufficiency and they were willing to get educated about this issue.

Keywords: Airway obstruction, child, foreign bodies, school teachers

Address for correspondence: Dr. Süleyman Utku Uzun. Department of Public Health, Epidemiology Division, Pamukkale University Faculty of Medicine, Denizli, Turkey

Phone: +90 5398707039

E-mail: utkuuzun402@gmail.com

Received Date: 28.01 .2020

Accepted Date: 31.03 .2020

Published online: 21.08 .2020

@Copyright 2020 by Anatolian Journal of Family Medicine Available online at www.anatoljfm.org

\section{INTRODUCTION}

Foreign body airway obstruction (FBAO) arises from an object which is placed on a child's mouth by himself/herself or given by someone. ${ }^{[1]} \mathrm{FBAO}$ is one of the most frequent causes of sudden unexpected deaths in childhood accidentally. ${ }^{[2]}$ In these cases, it is very important that making a correct diagnosis quickly and taking out the foreign body safely. ${ }^{[3]}$

Foreign bodies that cause airway obstruction differ from country to country. In various studies conducted in Europe and America, it has been reported that foreign bodies which most frequently cause airway obstruction are peanut and other nutrients in children and dental prosthesis and nutrient remnants in adults. ${ }^{[3-5]}$ In the Middle East, $66.3 \%$ of the FBAOs occurs due to watermelon seeds. ${ }^{[6]}$

Just as a large foreign body may escape to the airway and cause sudden death with full blockage of the respiratory tract; also, a small foreign body may also cause hypoxic attack resulting in death by laryngospasm. ${ }^{[6,7]}$ 
Preschool period is the risk period for FBAO. FBAO can be seen in all ages, but $85 \%$ of the cases are children aged under three. ${ }^{[8,9]}$ FBAO is the most frequent cause of death in children aged under five. ${ }^{[2,10]}$

Although childhood accidents happen at home primarily, then in the gardens and in the streets, the accidents happen at school are considerable as well. ${ }^{[11-13]}$ Preschoolers spend one third of their day and $14 \%$ of their total time at school. Besides, $10-25 \%$ of the most common accidents which are seen in childhood period, such as FBAO, burnt, hemorrhage, trauma and poisoning happen at school. ${ }^{[14]}$ Any person may encounter any situation that requires first aid during a lifetime. It was possible to save lives by performing first-aid practices. ${ }^{[15]}$

The teachers who are interested in the education of preschool children have the most effective educational roles in preventing accidents. ${ }^{[16]}$ Deaths related to FBAO are considered to be totally preventable deaths by ensuring that children, families and caregivers are trained, aware of the danger in children playing with small toys and objects. ${ }^{[17]}$

This study aims to investigate the knowledge levels of the preschool teachers who work in Denizli city center in Turkey about airway obstruction due to foreign body.

\section{METHOD}

The population of this cross-sectional study consists of 432 preschool teachers working in primary schools and kindergartens located in Denizli city center. The number of the individuals of the population was calculated according to sample size formula for finite populations ( $N=432, a=0.05$, $p=0.50, d=0.05$ ) and sample size, which would represent the population, was found as 204 teachers. Preschool teachers were determined from 27 schools that 11 of them were kindergartens, and 16 of them were primary schools. The data of this study were collected between 22.10.2012 22.02.2013 by visiting each of 27 schools by making at least two visits.

As a result of excluding the teachers, whose data could not be collected for various reasons, such as not being at the school on studying days, refusing the questionnaire, and appointment to another city/school, we contacted with 189 preschool teachers in total (92.6\%).

In the schools where the questionnaires were applied, firstly, administrative staff was notified about the aim of the study. Participant teachers were informed about this research and written permission was obtained. The teachers who participated in this study were conducted a questionnaire with 28 questions about personal information and past experiences (first part) and FBAO knowledge (second part).
The second part of the questionnaire has three sections as follows: Section $A$ is about the initial diagnosis of FBAO, and to decide whether the obstruction is to be interfered with or not, section B is about interventions to be performed in case of complete obstruction of the airway for infants aged $<1$ year and section $C$ is about interventions to be performed in case of complete obstruction of the airway for children aged $>1$ year. The questions of the second part were prepared based upon European Resuscitation Council Guidelines for Resuscitation 2010 and Turkey Ministry of Health, General Directorate of Primary Health Care Services, Advanced Life Support in Children program. ${ }^{[18,19]}$ Before and after the preparation of the questionnaire, it was evaluated by the experts and shaped according to their opinions. Before the questionnaire was applied to the sample group, it was applied as a pilot study on a group of 10 people and after the necessary corrections were made, the questionnaire was put into the final form. The questionnaire was applied to the teachers who accepted to participate in the survey by visiting the schools of the sample group. Questionnaires were left for the teachers who were absent from the school on study days or who indicated that they could fill in the questionnaire later.

FBAO knowledge score was calculated for each participant. Each participant can have 1 point for each correct answer out of 28 questions of the second part of the questionnaire. According to this, each participant could have the lowest 0 and the highest 28 points.

The data were evaluated in the SPSS program. Frequency, percentage, mean and standard deviation, median, minimum and maximum values were used as descriptive statistics. The Kolmogorov-Smirnov test, skewness and kurtosis statistics were used for normality distribution of data. Mann-Whitney-U test and Kruskal Wallis test, as well as multiple linear regression analysis, were used to determine the factors affecting knowledge status about FBAO. Data that were not normally distributed were normalized with logarithmic transformation. Multivariate analysis was conducted with multiple linear regressions with logarithmic-transformed response data. For the multiple regressions, continuous predictor data were left continuous, and categorical data were coded with indicator variables. All results with $p$-value under 0.05 were accepted statistically significant.

\section{RESULTS}

The mean age of the teachers who participated in this study was $33.5 \pm 5.3$ years and $185(98.4 \%)$ of them were female. One hundred sixty-two (86.6\%) of the participants were married, $21(11.2 \%)$ were single, and $146(77.7 \%)$ of 
the participants had children. The median number of children of teachers was 1.0 (1.0-3.0) child. The median professional time of the teachers was $10.0(2.0-34.0)$ years and 70 $(37.8 \%)$ of them were teaching for 6-10 years. The median year of schooling for teachers at the recent school was 3.0 (1.0-21.0) years. One hundred nineteen $(63.3 \%)$ of the teachers who participated in this study stated that they did not get any training about FBAO. One hundred forty-two (76.3\%) of them noted that their knowledge level was insufficient. One hundred fifty-one (80.7\%) of the teachers who participated in this study reported that they were willing to have training about FBAO (Table 1).

The first three emergencies that teachers encountered at school was questioned. One hundred fifty-four (84.1\%) of teachers indicated that they encountered epistaxis, 128 (67.7\%) of teachers encountered high fever and 80 (42.3\%) of teachers encountered head injury at school (not shown in Table). Only 23 (12.2\%) of the teachers stated that they came across FBAO before.

Section A consisted of 12 statements and this section was about the diagnosis of FBAO, the type of the obstruction and decision on whether to intervene in the obstruction or not. Only 26 (13.8\%) of teachers (the lowest score) responded correctly to this statement from section A: "It should be intervened if only symptoms of complete obstruction of airway due to a foreign body (such as food and toy parts)". One hundred and sixty (85.1\%) of teachers (the highest score) responded correctly to this statement from section A: "The skin color of a child is purple who suffers from a complete obstruction of airway due to foreign body (such as food and toy parts)".

Section B consisted of seven statements and this section was about intervenes to infants aged $<1$ year due to FBAO. Only 26 (19.4\%) of teachers (the lowest score) responded correctly to this statement from section B: "It should be delivered up back blows and chest thrusts to take out the foreign body safely". One hundred (53.5\%) of teachers (the highest score) responded correctly to this statement from section B: "Deliver alternating five back blows (between shoulder blades) and five chest thrusts (to the point where cardiac massage is performed)".

Section $C$ consisted of nine statements and this section was about intervenes to children aged $>1$ year in case of the complete obstruction of airway due to foreign body. Only $33(17.6 \%)$ of teachers (the lowest score) responded correctly to this statement from section C: "Water should be assumed as a foreign body, and the same intervenes should be performed in drowning children". One hundred two (55.1\%)
Table 1. Socio-demographic characteristics of the teachers

n (\%)

$\begin{array}{ll}\text { Age group (years) } & \\ 24-29 & 43(23.8) \\ 30-35 & 67(37.0) \\ 36-40 & 47(26.0) \\ \geq 41 & 24(13.2) \\ \text { Gender } & \end{array}$

Women

$185(98.4)$

Men

Marriage Status

Married

$162(86.6)$

Single

21 (11.2)

Widowed/Divorced

4 (2.2)

Have Children

Yes

146 (77.7)

No

$42(22.3)$

Number of Child

1

$73(50.0)$

$\geq 2$

$73(50.0)$

Working Years as Teacher (years)

0-5

6-10

$11-15$

49 (26.5)

$\geq 16$

33 (17.9)

Working years as teacher in current school (years)

0-5

$154(83.7)$

6-10 $18(9.8)$

$11-15$ 9 (4.9)

$\geq 16$

3 (1.6)

Situation of encountering FBAO before

Yes

No

$166(87.8)$

Received any training about FBAO

Yes

No

$119(63.3)$

Thinking that he/she has enough knowledge about FBAO

Yes

$44(23.7)$

No

$142(76.3)$

Willing to receive training about FBAO

Yes

$151(80.7)$

No

36 (19.3)

FBAO: Foreign Body Airway Obstruction.

of teachers (the highest score) responded correctly to this statement from section C: "For Heimlich maneuver, make a fist with one hand place the thumb side of your fist on the middle of the breastbone." 
The median FBAO knowledge score of all teachers who participated in this study was $13.0(0.0-24.0)$. The median knowledge score of teachers aged $\geq 41$ years old, who have two or more children, who received training for FBAO, who think they had sufficient knowledge level about FBAO, who were willing to receive further training were found significantly higher $(p=0.018, p=0.003, p<0.001, p<0.001$, $p<0.001$, respectively). Knowledge scores of teachers about the FBAO is presented in Table 2.

A multiple linear regression model (backward) was used to assess significant factors to the FBAO knowledge score. The variables which were found to be statistically significant were included in the regression model. Regression analysis revealed that receiving training about FBAO, willing to receive further training about the FBAO, and having two or more children were significantly related to the FBAO knowledge score (Table 3).

\section{DISCUSSION}

This study was conducted to investigate the knowledge levels of FBAO in preschool teachers working in Denizli city center in Turkey, and $96.8 \%$ of the teachers stated that they encountered emergencies (most frequently epistaxis, high fever and head injury) in the school. Besides, $12.2 \%$ of the teachers stated that they came across FBAO. Other studies showed that teachers have encountered emergencies with a high frequency, which requires first aid at a high frequency at school, as it is in our study. ${ }^{[15,20]}$ In another study, 38.6\% of the participants indicated that they came across FBAO. ${ }^{[21]}$ As it is seen in our study and in other studies, emergencies that require first aid were frequently encountered at schools. The incidence of mortality and morbidity cannot be underestimated if FBAO is not treated promptly and correctly. Thus, training about first aid and FBAO were required in schools.

In our study, the mean FBAO knowledge score of teachers was found as $11.6 \pm 5.5$. When the knowledge score range is considered, this result suggests that the knowledge level of FBAO in preschool teachers is low. In the literature, there are studies intended to measure first-aid knowledge levels of the staff who are working in educational institutions. However, our study was planned and carried out to measure knowledge on only one subject. This study (which includes all the steps of diagnosis and interventions to be performed about FBAO) was planned and implemented to measure the knowledge on only FBAO, which is one of the causes of preventable deaths. To our knowledge, there are no studies in the same direction; thus, the results of our study have been compared with other closest studies.
Table 2. Knowledge scores of the teachers about foreign body airway obstruction

Knowledge Score

Median (min-max) p

Age group (years)

24-29

$11.0(0.0-22.0)$

30-35

$13.0(0.0-22.0)$

$36-40$

$11.0(0.0-21.0)$

$\geq 41$

$14.5(4.0-19.0)$

Gender

$\begin{array}{ll}\text { Women } & 12.0(0.0-22.0) \\ \text { Men } & 13.0(4.0-21.0)\end{array}$

$0.830^{\dagger}$

Marriage Status

Married

$13.0(0.0-22.0)$

Single/Widowed/Divorced

$11.0(0.0-19.0)$

$0.136^{\dagger}$

Have children

Yes

$13.0(0.0-22.0)$

No

$10.0(0.0-21.0)$

$0.104^{+}$

Number of child

1

$11.0(0.0-22.0)$

$\geq 2$

$14.0(0.0-22.0)$

$0.003^{\dagger}$

Working years as

teacher (years)

0-5

$10.0(0.0-22.0)$

6-10

$13.0(0.0-22.0)$

11-15

$11.0(1.0-22.0)$

$\geq 16$

$13.0(0.0-22.0)$

$0.588^{*}$

Working years as teacher

in current school (years)

0-5

$13.0(0.0-22.0)$

6-10

$12.0(1.0-22.0)$

11-15

$10.5(0.0-19.0)$

$0.500^{*}$

$\geq 16$

$11.0(9.0-13.0)$

Situation of encountering

FBAO before

Yes

$14.0(1.0-22.0)$

No

$12.5(0.0-24.0)$

$0.366^{+}$

Received any training

about FBAO

Yes

$15.0(0.0-24.0)$

No

$10.0(0.0-22.0)$

$<0.001^{\dagger}$

Thinking that he/she

has enough knowledge

about FBAO

Yes

$15.5(1.0-22.0)$

No

$10.0(0.0-24.0)$ 
Table 2. CONT.

\begin{tabular}{|c|c|c|}
\hline & Knowled & core \\
\hline & Median (min-max) & $\mathbf{p}$ \\
\hline Willing & & \\
\hline about F & & \\
\hline Yes & $11.0(0.0-24.0)$ & \\
\hline No & $14.0(0.0-22.0)$ & $<0.001^{\top}$ \\
\hline
\end{tabular}

In a study, it is found that the mean score of knowledge about first-aid and basic life support of preschool teachers was 48.9. ${ }^{[22]}$ Another study found that the mean firstaid knowledge score was $7.0 \pm 1.9$ among teachers. ${ }^{[20]}$ In a study, which was conducted among primary school teachers, first-aid knowledge levels were tested and $92 \%$ of them responded 16 or more questions correctly (out of 25 questions) and their levels of knowledge were evaluated as good and very good. ${ }^{[23]}$ In another study, the mean first-aid knowledge score of the students of education faculty was found to be $47.8 \pm 11.2 .{ }^{[24]}$ When these results are taken into consideration, it is seen that the mean knowledge score of the teachers who participated in our study is lower than the scores of similar studies. The reason is that our study is not about first-aid practices in general, but rather particularly about a specific topic and that we conducted a detailed questionnaire about FBAO.

We found that teachers who received training about FBAO had higher knowledge scores than untrained teachers. Similarly, other studies found that the knowledge level of teachers who received training about first aid was higher. $[15,20,24,25]$ The effects of training on the knowledge levels cannot be denied, but even the trained teachers' mean knowledge score was 13.7, and that reveals that neither group has enough knowledge. Thus, the competency of the person or organization providing the training is also impor- tant. It is especially important that training about this topic should be given regularly by health professionals.

Besides, $63.3 \%$ of the teachers who participated in this research stated that they did not receive any training about FBAO, $76.3 \%$ of the teachers stated that their knowledge level was insufficient and $80.7 \%$ stated that they were willing to receive training about FBAO. Similar to our study, in many previous studies, the findings showed that the vast majority of teachers did not receive training about first aid, their knowledge level was insufficient and they wanted to receive training. ${ }^{[15,20-22,25-27]}$ When these results are evaluated together with the likelihood of encountering an emergency in schools, the necessity of the training about FBAO is obvious and it should be emphasized that training is important.

In this study, it was found that knowledge scores of the teachers who had two or more children were higher. This may be because teachers who have children are more interested in emergencies in children and that may be they have experienced such emergencies in their own children.

As it is seen in our study and in similar previous studies, first-aid training which should be received by the staff working in preschool institutions are insufficient. Also, first-aid training about FBAO, which is subject of our study, is insufficient. Teachers found their level of knowledge insufficient as well. The percentage of teachers who found their knowledge levels insufficient was higher than the teachers who did not receive training. It is thought that the reason for that is maybe the education they received was inadequate or that the training was not given periodically.

\section{CONCLUSION}

The findings obtained in this study showed that pre-school teachers in Denizli have insufficient knowledge about FBAO. Teachers were also aware of this lack of knowledge and wanted to receive training. It is necessary to make in-

Table 3. Multiple regression analysis of the factors that affect knowledge scores about foreign body airway obstruction

\begin{tabular}{|c|c|c|c|c|}
\hline & $\begin{array}{c}\text { Unstandardized } \\
\text { B }\end{array}$ & \multicolumn{3}{|c|}{ Confidence Interval } \\
\hline Received any Training about FBAO & 3.207 & 0.802 & $1.624-4.791$ & $<0.001$ \\
\hline Having $\geq 2$ Children & 2.002 & 0.972 & $0.436-3.568$ & 0.013 \\
\hline
\end{tabular}

FBAO; Foreign Body Airway Obstruction.

After logarithmic transformation, backward linear regression was performed. Following variables were in the model: Age, the number of children, the situation of receiving any training about FBAO, the situation of willing to receive training about FBAO and thinking that he/she has enough knowledge about FBAO. 
service training plans for pre-school teachers, to design training modules related to FBAO and also to schedule training courses periodically. In addition to this, it is suggested that the education faculties should add such kind of lectures to the curriculum. It is also recommended that the planned training should be given by health professionals, the training should include the practices about FBAO and the effectiveness of the training should be evaluated at the end of the course.

\section{Disclosures}

Peer-review: Externally peer-reviewed.

Conflict of Interest: None declared.

Ethics Committee Approval: This study was approved by Pamukkale University Faculty of Medicine Non-interventional Clinical Research Ethics Board, under protocol number 201214 (Approval date: 28.08.2012), in accordance with the Helsinki Declaration of 1975. Also, written permission was obtained from Denizli Provincial Directorate for National Education.

Authorship Contributions: Concept - H.G., A.E.; Design - H.G., A.E.; Supervision - A.E.; Materials - H.G.; Data collection \&/or processing - H.G.; Analysis and/or interpretation - H.G., S.U.U., A.E.; Literature search - H.G., S.U.U.; Writing - H.G., S.U.U.; Critical review - A.E., S.U.U.

\section{REFERENCES}

1. Pekcan S, Aslan TN. Foreign body aspirations in childhood. Turkish J Pediatr Dis 2010;4:119-28.

2. Ozdemir C, Uzün I, Sam B. Childhood foreign body aspiration in Istanbul, Turkey. Forensic Sci Int 2005;153:136-41.

3. Friedman EM. Tracheobronchial foreign bodies. Otolaryngol Clin North Am 2000;33:179-85.

4. Baharloo F, Veyckemans F, Francis C, Biettlot MP, Rodenstein DO. Tracheobronchial foreign bodies: presentation and management in children and adults. Chest 1999;115:1357-62.

5. Swanson KL, Prakash UB, Midthun DE, Edell ES, Utz JP, McDougall JC, et al. Flexible bronchoscopic management of airway foreign bodies in children. Chest 2002;121:1695-700.

6. Elhassani NB. Tracheobronchial foreign bodies in the Middle East. A Baghdad study. J Thorac Cardiovasc Surg 1988;96:6215.

7. Smitheringale A. Management of foreign bodies of the tracheobronchial tree. In: Pearson editor. Thoracic surgery. Philadelphia: Churchil Livingstone; 1995. p. 1591-9.

8. Blazer S, Naveh Y, Friedman A. Foreign body in the airway. A review of 200 cases. Am J Dis Child 1980;134:68-71.

9. Salih AM, Alfaki M, Alam-Elhuda DM. Airway foreign bodies: A critical review for a common pediatric emergency. World J Emerg Med 2016;7:5-12.

10. Lifschultz BD, Donoghue ER. Deaths due to foreign body as- piration in children: the continuing hazard of toy balloons. J Forensic Sci 1996;41:247-51.

11. Towner E, Therese D, Errington G, Burkes M, Towner J. Injuries in children aged 0-14 years and inequalities. London, UK: Health Development Agency; 2005.

12. Ferguson A. Child accident prevention as a health promotion issue--how extensive is the problem and how far have $A \& E$ departments responded to the recommendations made?. Accid Emerg Nurs 1994;2:193-99.

13. Thomson JA. Child pedestrian accidents: what makes children vulnerable?. In: Gillham B, Thompson J, editors. Child safety: problem and prevention from pre-school to adolescence. London, UK: Routledge; 2005. p. 76-93.

14. Sapien RE, Allen A. Emergency preparation in schools: a snapshot of a rural state. Pediatr Emerg Care 2001;17:329-33.

15. Dinçer Ç, Atakurt $Y$, Şimşek I. A study on the level of the first aid knowledge of educators working in preschools. J Ankara Univ Fac Med 2000;53:31-8.

16. Avery JG, Jackson RH. Children and their accidents. London, UK: Edward Arnold; 1993.

17. Bhana BD, Gunaselvam JG, Dada MA. Mechanical airway obstruction caused by accidental aspiration of part of a ballpoint pen. Am J Forensic Med Pathol 2000;21:362-5.

18. Nolan JP, Soar J, Zideman DA, Biarent D, Bossaert LL, Deakin $C$, et al. European Resuscitation Council Guidelines for Resuscitation 2010 Section 1. Executive summary. Resuscitation 2010;81:1219-76.

19. Turkey Minisrty of Health General Directorate of Primary Health Care Services. Advanced life support in children 2010. Avaliable at: https://sbu.saglik.gov.tr/Ekutuphane/Yayin/418. Accessed Apr 2, 2020.

20. Nayir T, Uskun E, Türkoğlu H, Uzun E, Öztürk M, Kişioğlu AN. The first aid knowledge levels and attitude of the teachers who work in Isparta city center. Med J SDU 2011;18:123-27.

21. Çelik, N. The effect of education offered to the students in child development department on their knowledge level about foreign body aspiration [Article in Turkish]. Unpublished Master's Dissertation, 2012. Council of Higher Education Thesis Center. Avaliable at: https://tez.yok.gov.tr/UlusalTezMerkezi/giris.jsp. Accessed Apr 2, 2020.

22. Yurumez Y, Yavuz Y, Saglam H, Koken R, Tunay K. Evaluation of the level of knowledge of first aid and basic life support of the educators working in preschools. Eurasian J Emerg Med 2007;5:17-20.

23. Uşakli H, Cengiz N. Uşak II Merkezinde Görevli Sınıf Öğretmenlerinin ilkyardım Bilgi Seviyelerinin Araştırılması. Afyon Kocatepe Üniversitesi Sosyal Bilimler Enstitüsü Sosyal Bilimler Dergisi 2001;2:24-6.

24. Bildik F, Kılıçaslan İ, Doğru C, Keleş A, Demircan A. The need for first aid awareness among candidate teachers. Tr J Emerg Med 
2011;11:166-70.

25. Gündüz S, Çizmeci MN, Kanburoğlu MK. Knowledge levels of teachers in preschool education institutions. Turkish J Pediatr Dis 2013;1:21-6.

26. Erkan G, Göz F. Öğretmenlerin İlk Yardım Konusundaki Bilgi Düzeylerinin Belirlenmesi. Atatürk Üniversitesi Hemşirelik
Yüksekokulu Dergisi 2006;9:63-8.

27. Bölükbaş N, Kahraman AN, Karaman Y, Kalaycı G. Ordu İli Kız Meslek Lisesi Çocuk Gelişimi Bölümü Son Sınıf Öğrencilerinin Çocuklara Yönelik İlk Yardım Uygulamaları İle İlgili Bilgi Düzeyleri. Atatürk Üniversitesi Hemşirelik Yüksekokulu Dergisi 2007;10:52-9. 